\title{
The introduction of the IBD Disk in Poland - a new tool for assessing disability in patients with inflammatory bowel disease
}

\author{
Piotr Eder ${ }^{1}$, Ariel Liebert ${ }^{2}$, Michał Łodyga ${ }^{3}$, Magdalena Kaniewska ${ }^{3}$, Maria Kłopocka², Grażyna Rydzewska ${ }^{3,4}$, \\ Agnieszka Dobrowolska ${ }^{1}$, Subrata Ghosh ${ }^{5}$ \\ ${ }^{1}$ Department of Gastroenterology, Dietetics, and Internal Diseases, Poznan University of Medical Sciences, \\ H. Święcicki University Hospital, Poznan, Poland \\ 2Department of Gastroenterology and Nutritional Disorders, Collegium Medicum in Bydgoszcz, Nicolaus Copernicus University \\ in Torun, Poland \\ ${ }^{3}$ Department of Gastroenterology with IBD Subdivision of the Central Clinical Hospital of Ministry of Internal Affairs, Warsaw, \\ Poland \\ ${ }^{4}$ Faculty of Health Sciences, Jan Kochanowski University, Kielce, Poland \\ ${ }^{5}$ Institute of Translational Medicine, College of Medical and Dental Sciences, University of Birmingham, Birmingham, \\ United Kingdom
}

Gastroenterology Rev 2020; 15 (1): 55-59

DOI: https://doi.org/10.5114/pg.2019.85337

Key words: disability, inflammatory bowel disease, translation.

Address for correspondence: Piotr Eder MD, PhD, Department of Gastroenterology, Dietetics, and Internal Diseases, Poznan University of Medical Sciences, Heliodor Święcicki University Hospital, 49 Przybyszewskiego St, 60-355 Poznan, Poland, phone: +48 618691343 , fax: +48 6186913 14, e-mail: piotr.eder@op.pl

\begin{abstract}
Introduction: Inflammatory bowel disease (IBD) is a chronic disorder of the gastrointestinal tract, which can significantly deteriorate everyday functioning. We are, however, still lacking simple methods to assess the influence of IBD on patients' disability. IBD Disk is a new graphical tool that allows for a quick assessment of the influence of IBD on different aspects of everyday life.

Aim: To present the adaptation process of the IBD Disk in Poland.

Material and methods: The Polish IBD Working Group together with the Institute of Translational Medicine in Birmingham (United Kingdom) and a professional translational agency performed a translation and re-translation of the Polish version of the IBD Disk. After full agreement was achieved, the final Polish version was accepted. In the next step, its understandability and ease of use was assessed by using a semiquantitative scale (scale from 1 to 10 , where " 1 " means very easy to use, "10" means - very difficult to use).

Results: In the initial translation phase, the concordance between translation agency and experts was very high. In the re-translation phase only some stylistic and grammatical corrections were made. In the final step the general assessment of understandability of all items of the tool was high. Moreover, patients with IBD assessed the ease of use of the IBD Disk as very easy (median: 1.5 points, 95\% confidence interval: 1.0-2.0).

Conclusions: The Polish adaptation of IBD Disk directly reflects the original English version. Thus, it can be further used in the validation process among Polish IBD patients.
\end{abstract}

\section{Introduction}

Inflammatory bowel diseases (IBD), including Crohn's disease (CD) and ulcerative colitis, (UC) are chronic, inflammatory disorders of unknown aetiology involving the gastrointestinal tract. The most common symptoms of IBD encompass diarrhoea, abdominal pain, and weight loss; however, clinical manifestations can be very heterogeneous, depending on the disease location and phenotype [1]. Many patients receive aggressive immunosuppressive drugs in order to achieve clinical and endoscopic remission. Nevertheless, a significant number of patients require surgical treatment due to lack of response to pharmacological therapy or as a result of severe complications [1]. 
The prevalence of IBD is increasing worldwide in developed countries [2]. These epidemiological tendencies are also observed in Poland; however, there are no long-term Polish prospective data on IBD incidence. According to the Polish registry of $C D$, the number of CD patients exceeds 7000, but it is believed that these data are underestimated. According to the estimations of the Polish Gastroenterological Association, there are 10,000-15,000 CD and 35,000-40,000 UC patients in Poland, and these numbers are increasing [3]. Because both CD and UC concern mainly young patients, IBD has become a significant problem also from a sociological point of view in recent years. The disease burden has an influence on many aspects of the patient's functioning and decreases their overall quality of life [4]. In order to assess these phenomena objectively, an IBD Disability Index (IBD-DI) has been proposed [5]. This is a validated tool, which can help clinicians to guide different therapeutic decisions. Nevertheless, due to its complexity it is difficult to use it in everyday clinical practice. Lately, a simplified version of the IBD-DI has been developed: the IBD Disk [6]. This tool assesses the following 10 items: abdominal pain, body image, education and work, emotions, energy, interpersonal interactions, joint pain, regulating defecation, sexual functions, and sleep. The final version of the IBD Disk was created in a multistep consensus process and it is based on the similar Psodisk platform, which was developed for patients with psoriasis. It can be used in an outpatient setting, also as a mobile application, to give an immediate visual representation of patient-reported, IBD-related disability [6].

\section{Aim}

In this paper we present the methodological process of the adaption of the IBD Disk in Poland.

\section{Material and methods}

The idea of the Polish adaptation of the IBD Disk arose during IBD Preceptorship in Birmingham in June 2018 (Subrata Ghosh, Piotr Eder). After the acceptance of Prof. Subrata Ghosh, the next steps were taken. In cooperation with the President of the Polish Gastroenterological Association, a working group was selected from Polish specialists in gastroenterology and IBD (Piotr Eder, Michał Łodyga, Ariel Liebert, Maria Kłopocka, Magdalena Kaniewska, Agnieszka Dobrowolska, Grażyna Rydzewska).

The IBD Disk is a 10-item visual instrument, which can be used also as a mobile application or application for personal computer (Figure 1). For each of the questions related to 10 categories, the patient should score his or her level of agreement on a scale of 0 to
10, where 0 means "absolutely disagree" and 10 means "absolutely agree" (Table I). In the next step the patient should circle all the scores on a coloured disc, which gives the final graphic visualisation of the current disability burden of the disease [6].

In order to adapt the IBD Disk for Polish doctors and patients, a multistep process was initiated. In the first step the English version of the IBD Disk was translated into Polish language, separately, by the members of the working group and by a professional translation agency (the translation phase). Then, after comparing and discussing all translations, the working group accepted in an on-line manner the final version after full agreement was achieved. In the next step, re-translation of the Polish IBD Disk version into English language was conducted by a professional translation agency (the re-translation phase). Then, the concordance of the re-translated version with the original one was assessed by the members of the working group. After full agreement was achieved, the final Polish version was accepted. In the last step the Polish IBD Disk version was sent to 10 persons (nurses, dietitians, students) in order to assess the understandability of the items used in the application. Moreover, 50 consecutive IBD patients were asked to rate the ease of use of the tool in a semiquantitative scale from 1 to 10 , where 1 means "very easy" and 10 means "very difficult".

\section{Results}

In the initial translation phase, the concordance between translation agency and experts was very high. There was only some discrepancy concerning the term "Sexual functions", because a direct Polish translation seems not to be suitable and does not reflect the original meaning of this item. We were considering two options referring more to "Sexual activity" or "Sexual functioning", finally accepting the Polish version "Funkcjonowanie seksualne".

In the re-translation phase only some stylistic and grammatical corrections were made. In the final step the general assessment of understandability of all items was high. Moreover, patients with IBD assessed the ease of use of the IBD Disk as very easy (median: 1.5 points, $95 \%$ confidence interval: $1.0-2.0$ ).

Table I presents the questions related to the 10 main items of the IBD Disk in the original English version and in the final Polish version.

\section{Discussion}

The current approach to the care of patients with IBD should take into account not only the assessment of clinical symptoms and disease activity by using serological markers, endoscopic, and radiological meth- 


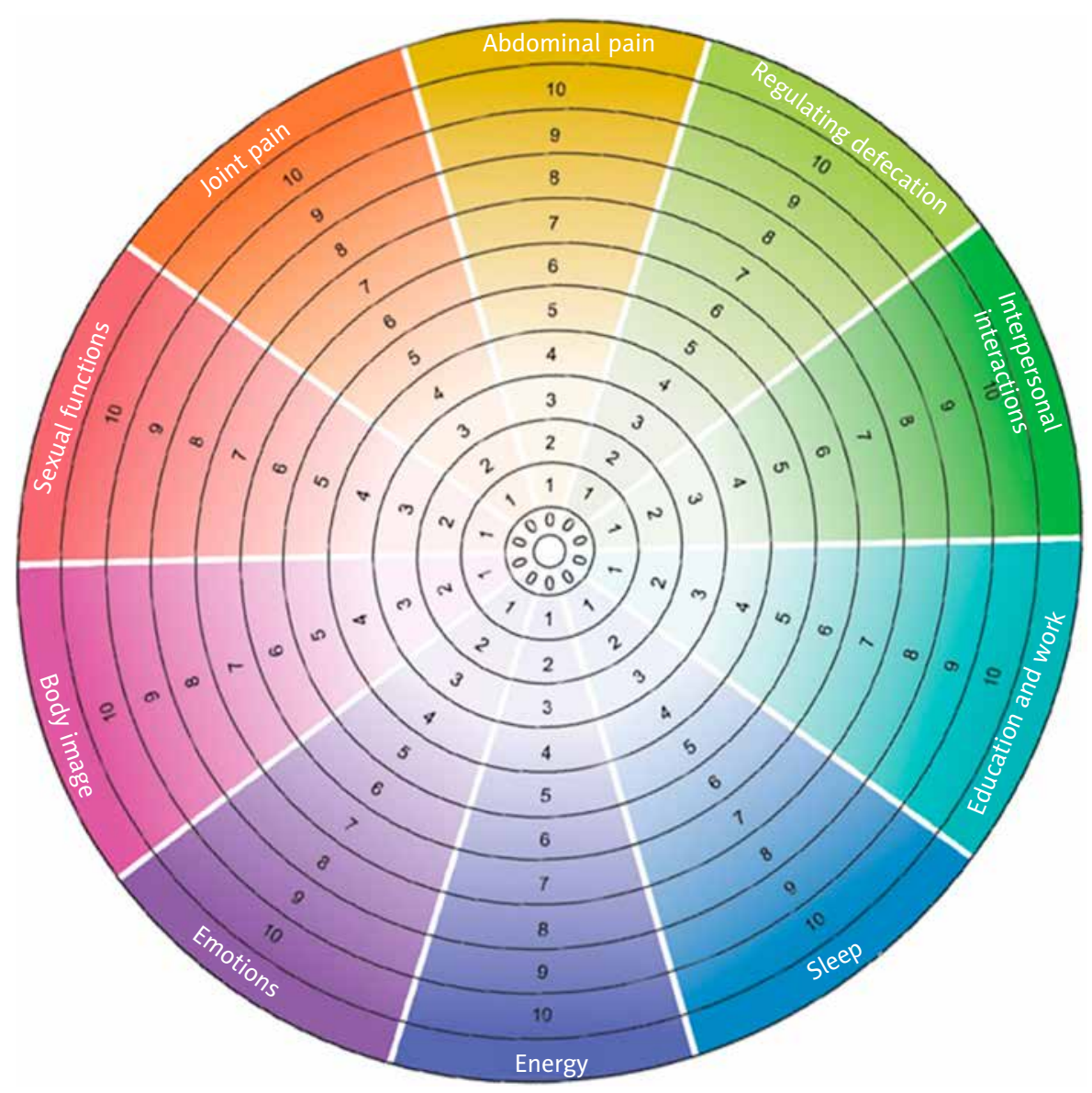

Figure 1. The IBD Disk visualisation. The circle contains 10 items related to disability, which are assessed by the patient (Source: Ghosh et al. Inflamm Bowel Dis 2017; 23: 333-40). See details in the text

ods, but also it should consider the influence of IBD on patients' everyday activity and functioning [7]. There are many data showing that active IBD can decrease the overall quality of life [4-6]. A significant proportion of patients develop anxiety and depression, which can also deteriorate the course of IBD [8]. Body image and self-acceptance are impaired, and the disease burden can result in sleep disturbances, can alter the ability to work, hinder everyday household activities, and limit educational opportunities [6, 9-12]. Moreover, IBD can lead to difficulties with personal relationships and participation in community, and very often it impairs sexual functions $[6,13]$. All of these phenomena worsen the everyday functioning of patients with IBD and cause disability.

Because clinicians were lacking a reliable tool assessing disability in IBD, a dedicated and validated tool for this purpose was proposed - the IBD-DI [5]. The published version of this questionnaire comprises 28 items covering different aspects of disability $[5,6]$. A modified version of the IBD-DI was also released, comprising
14 disability-related questions [14]. Nevertheless, using the IBD-DI can be time-consuming, and due to its complexity, it is difficult to use it more commonly in everyday clinical practice. The IBD Disk is a simplified version of the IBD-DI and was created in a sophisticated, methodological, multistep process in order to allow clinicians and patients to carry out practical implementation of routine assessment of disability in IBD [6]. The IBD Disk is aimed not only to dynamically assess the influence of chronic disease on different aspects of patients' life, but it also has the potential to help gastroenterologists to guide clinical decisions together with a patient. This holistic approach enables the estimation of a total disease activity/burden and is an example of a participatory medicine, in which the patient is actively engaged in medical care at all stages of the disease [6].

The main aim of adapting the IBD Disk in Poland was to improve the quality of care of Polish IBD patients. For several administrative reasons, the situation of this group of patients is difficult [15]. The reimbursement and practical introduction of the newest therapeutic mole- 
Table I. The table presents questions from the original English version of the IBD Disk and its final Polish translation

\begin{tabular}{|c|c|c|c|}
\hline \multicolumn{2}{|r|}{ English version } & \multicolumn{2}{|r|}{ Wersja polska } \\
\hline \multicolumn{2}{|c|}{$\begin{array}{l}\text { In the last week, because of my Crohn's disease or ulcerative } \\
\text { colitis: }\end{array}$} & \multicolumn{2}{|c|}{$\begin{array}{l}\text { W ostatnim tygodniu ze względu na chorobę Leśniowskiego- } \\
\text {-Crohna lub wrzodziejące zapalenie jelita grubego: }\end{array}$} \\
\hline Abdominal pain & $\begin{array}{l}\text {...I have had aches or pains in my } \\
\text { stomach or abdomen }\end{array}$ & Ból brzucha & $\begin{array}{l}\text {...odczuwałem (odczuwałam) } \\
\text { dyskomfort lub ból brzucha }\end{array}$ \\
\hline Regulating defecation & $\begin{array}{c}\text {...I have had difficulty coordinating } \\
\text { and managing defecation, including } \\
\text { choosing and getting to an appropriate } \\
\text { place for defecation and cleaning myself } \\
\text { afterwards }\end{array}$ & Kontrola wypróżnień & $\begin{array}{c}\text {...miałem (miałam) problemy } \\
\text { z kontrolowaniem wypróżnień, w tym } \\
\text { także problemy związane z wyborem } \\
\text { do tego celu odpowiedniego miejsca } \\
\text { i dotarciem tam oraz umyciem się po } \\
\text { wypróżnieniu }\end{array}$ \\
\hline $\begin{array}{l}\text { Interpersonal } \\
\text { interactions }\end{array}$ & $\begin{array}{l}\text {...I have had difficulty with personal } \\
\text { relationships and/or difficulty } \\
\text { participating in the community }\end{array}$ & Relacje międzyludzkie & $\begin{array}{l}\text {...miałem (miałam) problemy dotyczące } \\
\text { relacji osobistych z innymi ludźmi } \\
\text { i/lub związane z funkcjonowaniem } \\
\text { w społeczności }\end{array}$ \\
\hline Education and work & $\begin{array}{l}\text {...I have had difficulty with school or } \\
\text { studying activities, and/or difficulty with } \\
\text { work or household activities }\end{array}$ & Praca i edukacja & $\begin{array}{c}\text {...miałem (miałam) trudności } \\
\text { z wykonywaniem obowiązków w szkole } \\
\text { lub na uczelni i/lub obowiązków w pracy } \\
\text { lub w domu }\end{array}$ \\
\hline Sleep & $\begin{array}{c}\text {...I have had difficulty sleeping, such } \\
\text { as falling asleep, waking up frequently } \\
\text { during the night or waking up too early } \\
\text { in the morning }\end{array}$ & Sen & $\begin{array}{c}\text {...miałem (miałam) problemy ze snem, } \\
\text { takie jak problemy z zaśnięciem, częste } \\
\text { budzenie się w nocy lub zbyt wczesne } \\
\text { budzenie się rano }\end{array}$ \\
\hline Energy & $\begin{array}{c}\text { I have not felt rested and refreshed } \\
\text { during the day, and have felt tired and } \\
\text { without energy }\end{array}$ & Energia & $\begin{array}{l}\text {...nie czułem (nie czułam) się wypoczęty } \\
\text { (wypoczęta) i rześki (rześka) } \\
\text { w ciągu dnia, byłem (byłam) zmęczony } \\
\text { (zmęczona) i pozbawiony (pozbawiona) } \\
\text { energii }\end{array}$ \\
\hline Emotions & $\begin{array}{l}\text {...I have felt sad, low or depressed, and/ } \\
\text { or worried or anxious }\end{array}$ & Emocje & $\begin{array}{c}\text {...czułem (czułam) smutek, obniżenie } \\
\text { nastroju lub przygnębienie i/lub } \\
\text { zaniepokojenie lub lęk }\end{array}$ \\
\hline Body image & $\begin{array}{l}\text {...I have not liked the way my body or } \\
\text { body parts look }\end{array}$ & $\begin{array}{l}\text { Ocena własnego } \\
\text { wyglądu }\end{array}$ & $\begin{array}{l}\text {...nie podobał mi się wygląd mojego ciała } \\
\text { lub części mojego ciała }\end{array}$ \\
\hline Sexual functions & $\begin{array}{l}\text {...I have had difficulty with the mental } \\
\text { and/or physical aspects of sex }\end{array}$ & $\begin{array}{l}\text { Funkcjonowanie } \\
\text { seksualne }\end{array}$ & $\begin{array}{c}\text {...miałem (miałam) trudności } \\
\text { z psychicznymi i/lub fizycznymi } \\
\text { zagadnieniami dotyczącymi seksu }\end{array}$ \\
\hline Joint pain & $\begin{array}{l}. . .1 \text { have had pains in the joints of my } \\
\text { body }\end{array}$ & Ból stawów & ...bolały mnie stawy \\
\hline
\end{tabular}

cules (ustekinumab, vedolizumab) are delayed in Poland. The possibilities for optimal use of anti-TNF agents are increasing, but the maximum time period of the therapy is still only 2 years for $C D$ and 1 year in the case of UC. The number of physicians in Poland is among the lowest in Europe [16]. Thus, access to specialist medical care is difficult. On the other hand, Poland belongs to the most dynamically developing countries in Europe, with the lowest unemployment rates and the best economic ratings. The computerisation of Polish society and access to the latest technological achievements is vast. Moreover, Polish patients - especially at younger age, like those with IBD - are aware of their rights and want to actively participate in different pro-health initiatives by using media and mobile applications [17]. Polish associations supporting people with IBD are very active, and they support every opportunity to increase the social awareness of administrative and medical problems of this group of patients. Thus, introduction of the IBD Disk as a mobile application in Poland can improve the communication between gastroenterologists and patients, allowing better access to medical care. This could also be an opportunity to promote knowledge on IBD in Poland.

\section{Conclusions}

We performed a multistep adaptation process of the IBD Disk in Poland in order to offer a new scientific and clinical tool directly reflecting the original version. 
The next step for the IBD Disk in Poland, after launching the final version of this tool, will be to validate it in different cohorts of patients by comparing it with other well-known indices and scales, like the IBDDI, IBD-Questionnaire, Work Productivity and Activity Impairment Questionnaire: General Health (WPAI-GH) instrument, patient-based Simple Clinical Colitis Activity Index (p-SCCAI), and others in longitudinal, prospective, multicentre trials $[18,19]$. This step is crucial because the operating characteristics of the IBD Disk in clinical practice as an outpatient tool have not been fully validated [6]. All of those steps will be performed in strict cooperation with the Institute of Translational Medicine at the University of Birmingham. Then we plan to promote the use of the IBD Disk in everyday clinical practice among Polish gastroenterologists and Polish IBD patients in order to improve the quality of care in IBD in Poland.

\section{Acknowledgments}

The members of the working group would like to thank everyone (patients, students, nurses, dietitians) who participated in the adaptation process of the IBD Disk in Poland.

\section{Conflict of interest}

The authors declare no conflict of interest.

\section{References}

1. Fakhoury M, Negrulj R, Mooranian A, et al. Inflammatory bowel disease: clinical aspects and treatments. J Inflamm Res 2014; 7: 113-20.

2. Burisch J, Munkholm P. The epidemiology of inflammatory bowel disease. Scand J Gastroenterol 2015; 50: 942-51.

3. Koszty bezpośrednie i pośrednie ponoszone przez pacjentów z chorobą Leśniowskiego-Crohna. Raport Pex PharmaSequence. Warszawa, 22.05.2018. Available: https://www. pexps.pl/files/upload/files/PEX_KosztyPosrednieChorobaCrohna_20180626.pdf

4. Lonnfors S, Vermeire S, Greco M, et al. IBD abd health-related quality of life - discovering the true impact. J Crohns Colitis 2014; 8: 1281-6.

5. Peyrin-Biroulet L, Cieza A, Sandborn W, et al. Development of the first disability index for inflammatory bowel disease based on the international classification of functioning, disability and health. Gut 2012; 61: 241-7.

6. Ghosh S, Louis E, Beaugerie L, et al. Development of the IBD Disk: a visual self-administered tool for assessing disability in inflammatory bowel diseases. Inflamm Bowel Dis 2017; 23: 333-40.

7. Koltun WA. Better together: improved care for the IBD patient using the multi-disciplinary IBD center. Exp Rev Gastroenterol Hepatol 2017; 11: 491-3.

8. Gracie DJ, Guthrie EA, Hamlin PJ, et al. Bi-directionality of brain-gut interactions in patients with inflammatory bowel disease. Gastroenterology 2018; 6: 1635-46.
9. McDermott E, Mullen G, Moloney J, et al. Body image dissatisfaction: clinical features, and psychological disability in inflammatory bowel disease. Inflamm Bowel Dis 2015; 21: 353-60.

10. Kinnucan JA, Rubin DT, Tauseef A. Sleep and inflammatory bowel disease: exploring the relationship between sleep disturbances and inflammation. Gastroenterol Hepatol 2013; 9: 718-27.

11. Ramos A, Calvet X, Sicilia B, et al. IBD-related work disability in the community: prevalence, severity and predictive factors. A cross-sectional study. United European Gastroenterol J 2015; 3: 335-42.

12. Freckmann M, Seipp A, Laass MW, et al. School-related experience and performance with inflammatory bowel disease: results from a cross-sectional survey in 675 children and their parents. BMJ Open Gastroenterol 2018; 5: e000236.

13. Marin L, Manosa M, Garcia-Planella E, et al. Sexual functions and patients' perceptions in inflammatory bowel disease: a cross-control survey. J Gastroenterol 2013; 48: 713-20.

14. Gower-Rousseau C, Sarter H, Savoye G, et al. Validation of the inflammatory bowel disease disability index in a population-based cohort. Gut 2017; 66: 588-96.

15. Rencz F, Pentek M, Bortlik M, et al. Biological therapy in inflammatory bowel diseases: access in Central and Eastern Europe. World J Gastroenterol 2015; 21: 1728-37.

16. Krajewski-Siuda K, Szromek A, Romaniuk P, et al. Emigration preferences and plans among medical students in Poland. Hum Resour Helath 2012; 10: 8.

17. Marlicz W. World Digestive Health Day - WDHD Poland 2017 Inflammatory Bowel Diseases - challenges and hopes. Prz Gastroenterol 2018; 13: 82-4.

18. Taleban S, Stewart K, Li DK, et al. Clinical activity and quality of life indices are valid across ulcerative colitis but not Crohn's disease phenotypes. Dig Dis Sci 2016; 61: 2627-35.

19. Bennerbroek-Evertsz FB, Nieuwkerk PT, Stokkers P, et al. The Patient Simple Clinical Colitis Activity Index (P-SCCAI) can detect ulcerative colitis (UC) disease activity in remission: a comparison of the P-SCCAI with clinician-based SCCAI and biological markers. J Crohns Colitis 2013; 7: 890-900.

Received: 2.05 .2019

Accepted: 15.05 .2019 